\title{
Initiating the establishment of commercial stand at Tasik Besar Serkap, Riau, Indonesia: An early growth assessment of two peat swamp tree species
}

\author{
HENTI HENDALASTUTI RACHMAT ${ }^{\boldsymbol{v}}$, ATOK SUBIAKTO \\ Forest Research and Development Center. Jl. Gunung Batu No 5, Bogor 16118, West Java, Indonesia. Tel./fax. +62-251-8334314, \\ "email: hendalastuti@yahoo.co.uk
}

Manuscript received: 25 October 2018. Revision accepted: 28 December 2018

\begin{abstract}
Rachmat HH, Subiakto A. 2019. Initiating the establishment of commercial stand at Tasik Besar Serkap, Riau, Indonesia: An early growth assessment of two peat swamp tree species. Biodiversitas 20: 267-272. Degraded and converted peat swamp forest has enhanced the emission of $\mathrm{CO}_{2}$ and become one major contributor of huge greenhouse gas emission. Management unit at site level of KPH Tasik Besar Serkap covers a very wide area of more than 510.000 ha, dominated by $90 \%$ of peat swamp forest (PSF) which is susceptible to several disturbance sources (fires, illegal logging, land encroachment, alien species invasion, etc) and experiencing more deteriorated condition if there is no significant action carried out in managing its resources. Thus, it is important to improve the productivity of this PSF by planting it with native commercial tree species in order to maintain its role both in production and conservation aspects. The main objective of this study was to determine suitable PSF native species to rehabilitate highly degraded PSF in KPHP Tasik Besar Serkap. Two native PSF tree species were used namely Balangeran (Shorea balangeran) and Bintangur (Callophylum soulatri). Seedlings were planted at 4 x 3 meter spacing distance, each species was planted in a 1-ha plot, and thus the planting trial total area was 2 ha with 834 individual trees/species/ha. The survival rates at 6 months and 12 months after planting were $81.77 \%$ (682 seedlings/ha) and 58.6\% (488 seedlings/ha) respectively for Balangeran, and 12.64\% (105 seedlings/ha) and $10.34 \%$ ( 86 seedlings/ha) for Bintangur. The average heights at 6 and 12 months after planting for Balangeran were $111.54 \mathrm{~cm}( \pm 16.731)$ and $206.03 \mathrm{~cm}( \pm 30.905)$ respectively, while for Bintangur $60.00 \mathrm{~cm}( \pm 12.921)$ and $72.76 \mathrm{~cm}( \pm 11.326)$ respectively. We also observed physical damage on planted seedlings, namely the occurrence of shoot and twig boring (pest) and seedling mortality caused by herbicide contact when our field staff applied herbicide at the experimental plots to ease the planted seedlings from weeds and other competitors. Borer was only identified in the surviving Balangeran seedlings at 12 months after planting with the intensity of attack of $17 \%$. We did not observe similar case occurring in planted Bintangur. Seedling mortality rates caused by herbicide contact for Balangeran and Bintangur were 3.8\% and 3,2\% respectively. From the study result, it was concluded that only Balangeran was recommended to be planted for increasing the productivity of PSF in the scheme of commercial stand.
\end{abstract}

Keywords: native species, peat swamp forest, Shorea balangeran, commercial stand, Tasik Besar Serkap

\section{INTRODUCTION}

The peat swamp forest is a type of wetland, waterlogged almost all year round, with plants growing on the peat surface. A peat swamp forest is characterized by evergreen forest, a type of tropical rainforest. The forest is influenced by the edaphic factor in the soil, where the area has long been inundated with fresh water (Chamlong, Chavalit and Wiwat 1991; Thawatchai and Chavalit 1985). The forest also serves as a habitat and breeding ground for various species of wild animals. It has long been a fishing ground for villagers and a source of wild items, firewood, and timber. The peat swamp forest is economically important. It can be managed to provide agricultural, forestry, fishery and industrial benefits.

Peatlands in the world cover an area of about 436.2 million ha, mostly located in the temperate zone. Only 35.8 million ha or $8.2 \%$ of peatlands worldwide are found in the tropic and subtropic zones. Of these, $47.5 \%$ or 17 million ha are found in Indonesia (Andriesse 1988), mainly in the islands of Sumatra, Kalimantan and Irian Jaya (Simbolon and Mirmanto 1999), but most of these peatlands have been degraded (Siregar and Sambas 1999). The country in the tropic zone that has the second largest area of peatlands is Malaysia, with a total of 2.5 million ha (Andriesse 1988).

The extent of peat swamp forests (PSF) in Indonesia is around 18.9 million ha, of which 12.9 million ha is distributed mainly in 7 provinces including Riau, Jambi, South Sumatera, West Kalimantan, Central Kalimantan, South Kalimantan and Papua. Of those 12.9 million ha, only 5.2 million ha is primary peat swamp forest, while the other 7.7 million ha has been a secondary forest and open peat swamp (Peat Swamp Restoration Bureau. 2016). It is even more deplorable to learn that at present the peat swamp forests are being encroached upon and converted for agricultural purposes, and trees are cut for timber or charcoal production to the point beyond replacement. The most disturbing problem affecting peat swamp forests is wildfires, which often ravage the area during the dry season. It is a cause for great concern that in the future, fertile peat swamp forests might vanish completely from Indonesia. Therefore, it is vital that we take steps to prevent this from happening. 
Degraded and converted peat swamp forest has enhanced the emission of $\mathrm{CO}_{2}$ and become one major contributor of huge greenhouse gas emission. It is important to improve the productivity of degraded peat swamp by planting it with commercial tree species, in order to sustain its role as an important source of high-quality timber and also maintain its ecological benefit. Rehabilitation through planting of more plant species in the degraded areas of peat swamp forests is an effective way to restore fertility of the area. Planting and rehabilitating degraded peat swamp forests require different techniques and practices from those used for other types of forests (Tanit 1995). To attain effective results, planters and those who are involved with planting and rehabilitation must have a thorough understanding of such techniques and practices. In addition, the process needs the application of proper technical know-how. Otherwise, these degraded peat swamp areas will only be colonized by pioneer and invasive species and will lose their ecological and economic function.

Research on selecting original peat swamp tree species used for rehabilitation and establish commercial stand is necessary to be conducted on these areas. This project will function as a preliminary investigation on what option can be taken related to species selection and it increases the successfulness of reforestation and rehabilitation of degraded peat swamp forest other than those of utilization of exotic fast-growing trees. Among the local alternative species prospective to be planted in peat swamp forest substituting the current most widely acceptable Acacia crassicarpa are Shorea balangeran (Balangeran) and Callophylum soulatri (Bintangur). The objective of this research was to evaluate the early growth performance of two peat swamp tree species, Shorea balangeran and Callophylum soulatri and suggest what species can be the alternative of establishing more productive tropical peat swamp forest in Indonesia.

\section{MATERIALS AND METHODS}

\section{Plot site}

The plot site was located at Blok C of Forest Management Unit Tasik Besar Serkap, in Siak District, Riau, Indonesia (Figure 1). In general, it has slender topography with slopes ranging from 0 to $8 \%$. The site has altitudes ranging from 6 to $20 \mathrm{~m}$. The area of Forest Management Unit of Tasik Besar Serkap consists of almost $100 \%$ peat swamp area which is formed by young and old alluvial sediments, constituted from sand sediment, clay, and immature decaying plants and peat (KPH TBS, 2013). Soil is dominated by organosol which contains high amount of organic materials where soil development has been dominantly affected by maturity level of its constituents and also level of decomposition. The soil was characterized by the establishment of dark brown to blackish soil horizon with high content of moisture and high acidity $(\mathrm{pH} 3-5)$. Based on direct observation (FMU/REDD+KIJP, 2016), it could be seen that the maturity levels of surface peat layer $(0-50 \mathrm{~cm})$ were hemosapric and sapric, while the down layer was fibric and hemic.

\section{Procedures \\ Planting technique}

In total we established two one-ha plots for Balangeran and Bintangur. Spacing distance was set at $4 \times 3 \mathrm{~m}$. As the plots were in one intact uniform condition of almost open peat swamp area, we assumed that the condition (e.g. soil, microclimate, association) was uniform. One-ha plot (100 $\mathrm{m} \times 100 \mathrm{~m}$ ) per each species were set side by side as shown in Figure 2. Planting hole size was by $40 \mathrm{~cm}$ x $40 \mathrm{~cm} \times 30$ $\mathrm{cm}$ (length $\mathrm{x}$ wide $\mathrm{x}$ height). Seedling sizes of Balangeran were relatively homogeneous at the range of $45-55 \mathrm{~cm}$ in height while those of Bintangur were rather smaller at the range of $40-50 \mathrm{~cm}$. Planting activity was set at October considering that it was the start of rainy season. We did open planting, meaning that seedlings were planted directly in open area of the plots, and we did not use shade trees both for Balangeran and Bintangur. Open planting would require lower cost and the easiest method.

\section{Assessment of early growth}

Assessment of the field growth performance and survival rate of Balangeran and Bintangur was conducted 6 and 12 months after planting. The assessment of the growth performance involved measurements of tree height and survival rate. If the tree height did not exceed $1.3 \mathrm{~m}$, we did not conduct measurement of tree diameter. The tree total height was measured using trigonometry principles from ground level to the top part of the tree. For survival rate of the planted trees within the study plot, calculation was made using the following formula:

Survival rate, $\mathrm{X}=(\mathrm{Z} / \mathrm{Y}) \times 100 \%$

Where,

$\mathrm{X}=$ Survival rate of planted trees;

$\mathrm{Y}=$ Total planted trees;

$\mathrm{Z}=$ Total number of standing trees.

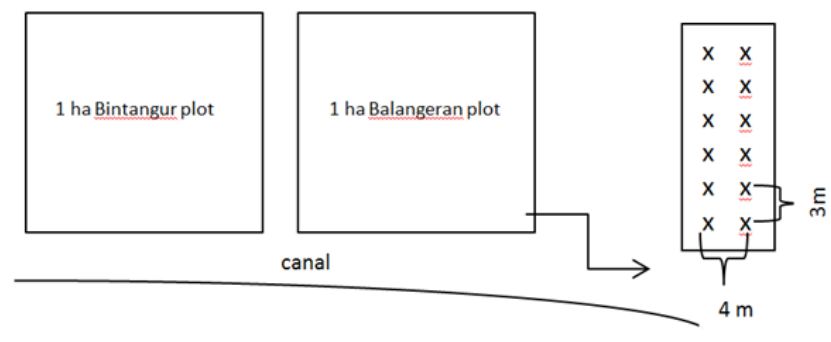

Main logging road

Figure 2. Outline of experimental plots using native peat swamp species of Balangeran and Bintangur. Spacing designed to be $4 \mathrm{x}$ 3 meter, each plot consisting of around 840 trees/ha 


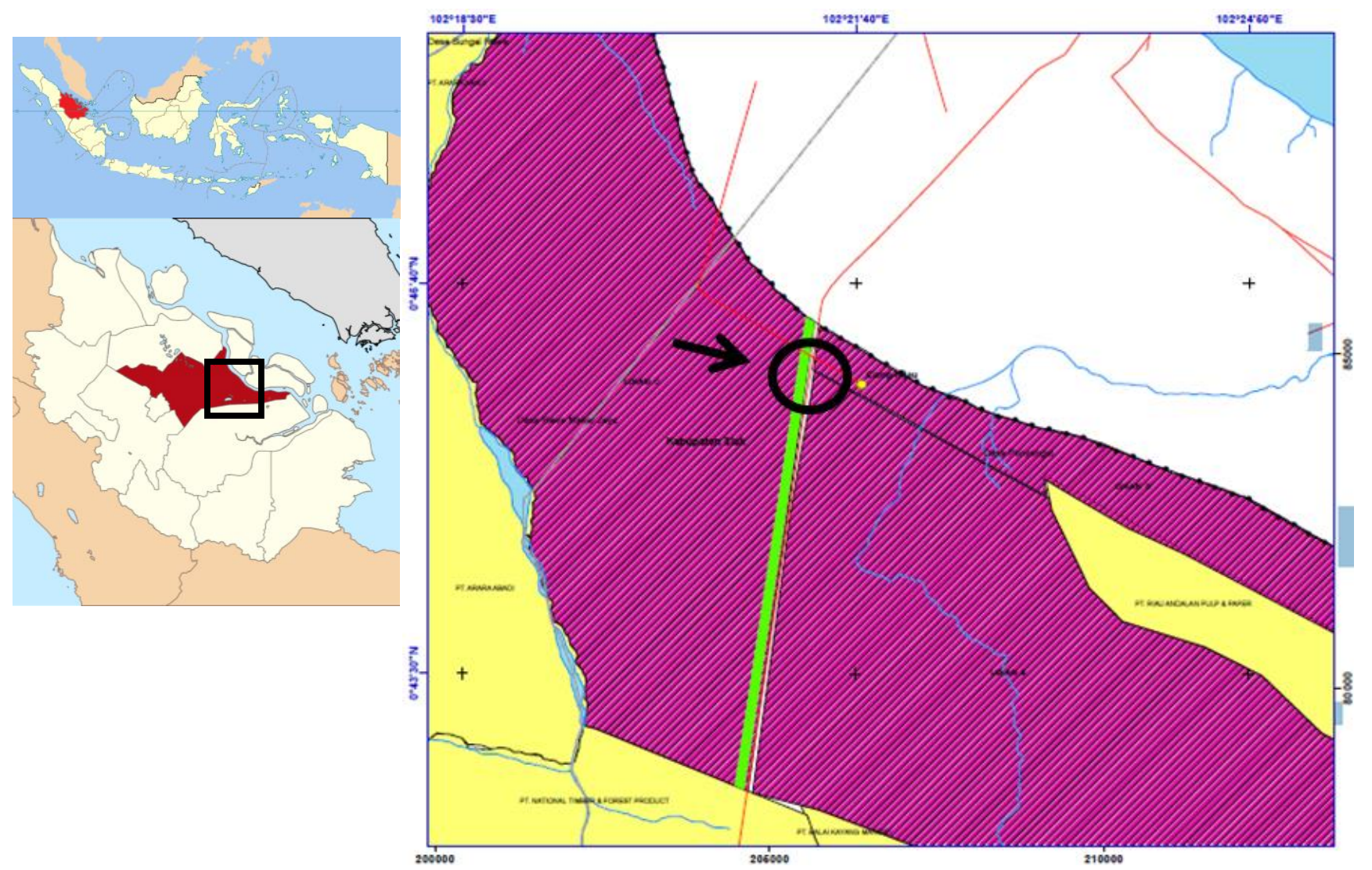

Figure 1. Planting location at Blok C (pointed by black cycle) of Forest Management Unit of Tasik Besar Serkap in Siak District, Riau, Indonesia

Assessment of pest attack and mortality caused by herbicide contact

As we observed that surviving Balangeran trees were attacked by borers, we evaluated the level of its attack on standing trees 12 months after planting. The level of pest attack was calculated using the following formula:

Pest attack, $\mathrm{X}=(\mathrm{Z} / \mathrm{Y}) \times 100 \%$

Where:

$\mathrm{X}=$ Level of pest attack;

$\mathrm{Y}=$ Total standing/surviving trees;

$\mathrm{Z}=$ Total number of effected/attacked trees.

We also applied physical and herbicide application to ease the seedlings from weeds. Physical weed removal requires more labor and time but we did not observe seedling death caused by this type of weed eradication. However chemical weeding by spraying herbicide had wider effect on planted seedlings as it might increase mortality rate to the surviving seedlings by means of direct contact between herbicide spray and planted seedlings. The level of mortality caused by herbicide contact was calculated using the following formula:

Mortality level, $\mathrm{X}=(\mathrm{Z} / \mathrm{Y}) \times 100 \%$
Where:

$\mathrm{X}=$ Level of seedlings affected;

$\mathrm{Y}=$ Total standing/survived trees;

$\mathrm{Z}=$ Total number of contacted trees with herbicide.

\section{Data analysis}

Data were analyzed by calculating the mean value of 6 and 12 month-old planted seedlings followed by calculating their standard deviation.

\section{RESULTS AND DISCUSSION}

Based on the Forestry Law No. 41/1999, Forest Management Unit (KPH, Kesatuan Pengelolaan Hutan) is an area of smallest forest management unit in accordance with its main function and its utilization that can be managed efficiently and on a sustainable manner. All state forests in Indonesia would be divided into KPH areas (Suwarno et al, 2014). KPH Tasik Besar Serkap has a very wide area of 513,276 ha and mostly dominated by peat swamp forests [KPH TBS, 2013]. The established plot site was adjacent to areal of Acacia crassicarpa plantation owned by Pt. Riau Andalan Pulp and Paper (RAPP). As regulated by Government Regulation GR No. 6/2007 jo GR No. 3/2008, and detailed implementation in FMD No. P.6/ 2010 regarding Norm, Standard, Procedure and Criteria of 
Forest Management in KPHL (Kesatuan Pengelolaan Hutan Lindung) and KPHP (Kesatuan Pengelolaan Hutan Produksi), the main tasks of KPH organization include all aspects of forest management (from forest management planning to socio-economy study), and that KPHs need to be self-sufficient to run their operational working activities. Among the efforts of implementing their self-sufficient management, establishing more productive forest landscape through planting activities need to be initiated.

Assessment of early growth of two native peat swamp species is described in Table 1. Each plot was planted with similar number of seedlings. Considering that the spacing distance was $4 \times 3 \mathrm{~m}$, each plot would be consisting of 834 seedlings/ha.

\section{Early growth performance of Balangeran and Bintangur}

Shorea balangeran (Korth.) Burck is a common and often gregarious species in tropical peat swamp forest. It is known to be found scatteredly in Bangka, Belitung and Kalimantan Island. Locally known as Balangeran, the species may attain a diameter up to $60 \mathrm{~cm}$ and a height of more than $30 \mathrm{~m}$ (Turjaman et al, 2011). Bintangur is grouped into Clusiaceae family which is naturally distributed in Indo China, Thailand, Malaysia, to Melanesia. In Indonesia, Bintangur can easily be found in Sumatera, Kalimantan and Papua (Lim dan Lemmens, 2010).

Our study showed that Balangeran and Bintangur performed different levels of success both in term of survival rate and also height increment. Table 1 shows that Balangeran had both higher survival rate and height increment. At 6 months after planting (map), Balangeran was almost two times as high as Bintangur, while at 12 maps, it was three times as high as Bintangur. Similar trend was reported by Lampela et al. (2017) who found that Balangeran had relative height increment of more than $100 \%$ at 1.5 years after planting. Table 1 shows that Bintangur had slower growth and lower survival rate. Our observation recorded that the death of Bintangur seedlings was first characterized by the drying of upper shoots followed by that of stems and leaves. Surviving seedlings were more often characterized by a decrease of seedlings height as the result of upper shoot drying. None of the individuals for both species experienced death caused by wildfires as the area had been monitored intensively and kept at high concern for forest fire prevention. Therefore, the drying of individuals was most likely caused by longer dry season at later year after planting. Open area and open planting technique applied here may be the cause for high mortality rate during the second measurement (12 maps) as during this period, dry season had longer duration than expected.

The survival rates of Balangeran $(81.77 \%, 58.56 \%$ at 6 and 12 map) also apparently showed similar trend with its height increment. Survival rates of Balangeran were higher than those of Bintangur (12.64\%, 10.34\% at 6 and 12 map). Compared to survival rate of intensively managed 4-year Bintangur stand at PT. Arara Abadi (Darwo \& Bogidarmanti, 2016), the survival rate at this study site was much lower. The level of stand tending is assumed to be the key factor for the different results. The level of stand tending at this study was lower than that of intensive management carried out in PT. Arara Abadi. In that plantation mineral fertilizer together with boiler ash was applied when Bintangur seedlings were planted, followed by frequent fertilizing at 1.4 and 12 months after planting. Weeding was also carried out as a routine activity during its early growth. However, in this study, there was no application of fertilizer, both mineral and organic fertilizers, as well as later fertilization during the first year. Weeding was also done once during the first year of its early growth. From this study, it was well understood that for Bintangur species, intensive care would significantly affect the number of surviving seedlings and height increment. However, similar study carried out by Takahashi et al. (2001), irrespective of preparation techniques of their trials, indicated that Shorea balangeran and Palaquium had considerably higher survival rates (65$100 \%)$ than the other species (6-65\%).

Balangeran showed remarkable tolerance for both less tending and site condition than Bintangur as indicated by higher survival rate and height increment. Longer dry season and inundation during rainy season had less impact on Balangeran than on Bintangur. Similar result was also shown by Lampela et al. (2017) when Balangeran was found as one of peat swamp native species that had great tolerance to both long dry season and inundation during the river flooding. According to Lavelle (1987), under an open area after clearing there will be dramatic changes observed in the temperature and moisture at surface soils. This later will create large diurnal range and dry and hot surface soils. Under such condition, nutrients will be lost rapidly through erosion and leaching, hence high water evaporation may lead to soil drying quickly (Lu et al. 2002). Furthermore, treeless open degraded areas are prone to strong fluctuations in the groundwater table (WT) leading to severe flooding during the rainy season and extreme drought during the dry season (Hirano et al. 2015; Jauhiainen et al. 2008), and those worsen the extreme fluctuation of growing site.

Table 1. Early growth performance of two native peat swamp forest tree species planted at FMU Tasik Besar Serkap, Riau, Indonesia

\begin{tabular}{lcc}
\hline Description & Balangeran & Bintangur \\
\hline $\begin{array}{l}\text { Number of planted seedlings/ha } \\
\text { Number of surviving } \\
\text { seedlings/ha }\end{array}$ & 834 & 834 \\
At 6 map & & \\
At 12 map & 682 & 105 \\
Survival rate (\%) & 488 & 86 \\
At 6 map & & \\
At 12 map & 81.77 & 12.64 \\
Average height (cm) & 58.56 & 10.34 \\
At 6 map & & \\
At 12 map & $111.54 \pm 16.731$ & $60.00 \pm 12.921$ \\
Pest attack (\%) & $206.03 \pm 30.905$ & $72.76 \pm 11.326$ \\
Mortality as exposed to & 17 & - \\
herbicide application (\%) & 3.8 & 3.2 \\
Note: Map (months after planted) & & \\
\hline
\end{tabular}

Note: Map (months after planted) 


\section{Pest attack and level of mortality caused by herbicide application}

Surprisingly we observed pest disturbance in our plots (Figure 3). Even though Balangeran showed better performance on both survival rate and height increment, but they could be invaded by pest that attacked both upper shoots and also main stems and secondary branches. The pest was identified as insect borer that bit and sucked both shoots and young stems or branches, leaving the tissue dried, browned, and dead. Out of the surviving Balangeran seedlings (58.56\%, 488 seedlings) $17 \%$ were attacked by borers. Those attacked in the upper shoot had decreased total height. However, shoot and young twig boring did not cause mortality but rather caused a decrease in their total height and induced the formation of multiple branching after destroying the main shoots. Even though shoot boring does not cause direct mortality, but this attack in reforestation programs or plantation establishment becomes more significant. As reported previously (Daljeet-Singh $1975)$ the attack of shoot boring insect caused more than $50 \%$ and up to $16.5 \%$ disturbance to $S$. acuminata and other Shorea species in their planting trial plots, while on $S$. teysmaniana seedlings, the shoot boring was the major factor of die-back (Shamsuddin 1991). Unfortunately, at the time of observation, the pest attack only left their destruction footprint as we did not observe any of the insect and or other stages of the insect.

To control weeds we did two types of eradication, namely physical removal by manually cleaning the weeds around the planted seedlings and chemical eradication by spraying contact herbicide with active component of triclopyr. Manual eradication required extra time and labors, but it is always nature-friendly, while herbicide required less time and less labor and thus it is more effective and efficient in eradicating weeds. Chemical application carried out by local staff, on the other hand, had diverse impacts to seedlings themselves. Improper application of herbicide contacted not only weeds but also seedlings themselves. Unintentional contact between herbicide and planted seedlings at certain level caused seedling mortality, especially in small-size seedlings. We observed $3.8 \%$ of mortality occurred in the surviving Balangeran seedlings and $3.2 \%$ in Bintangur seedlings because of such unintentional contact with herbicide application. Based on this experience, we proposed that herbicide application should be minimized due to its apparent impact on seedling mortality and also its environmental issue.

Slashing down of competitor trees as well as eradicating weeds for 1-year-old planted seedlings will support their growth in field. Manual removal of weeds around planted seedlings seems to be realistic when planted area is not very vast. However, commercial plantation will require vast area coverage, so manual removal seems not economically beneficial. Thus, nature-based herbicide may be one of the alternatives.

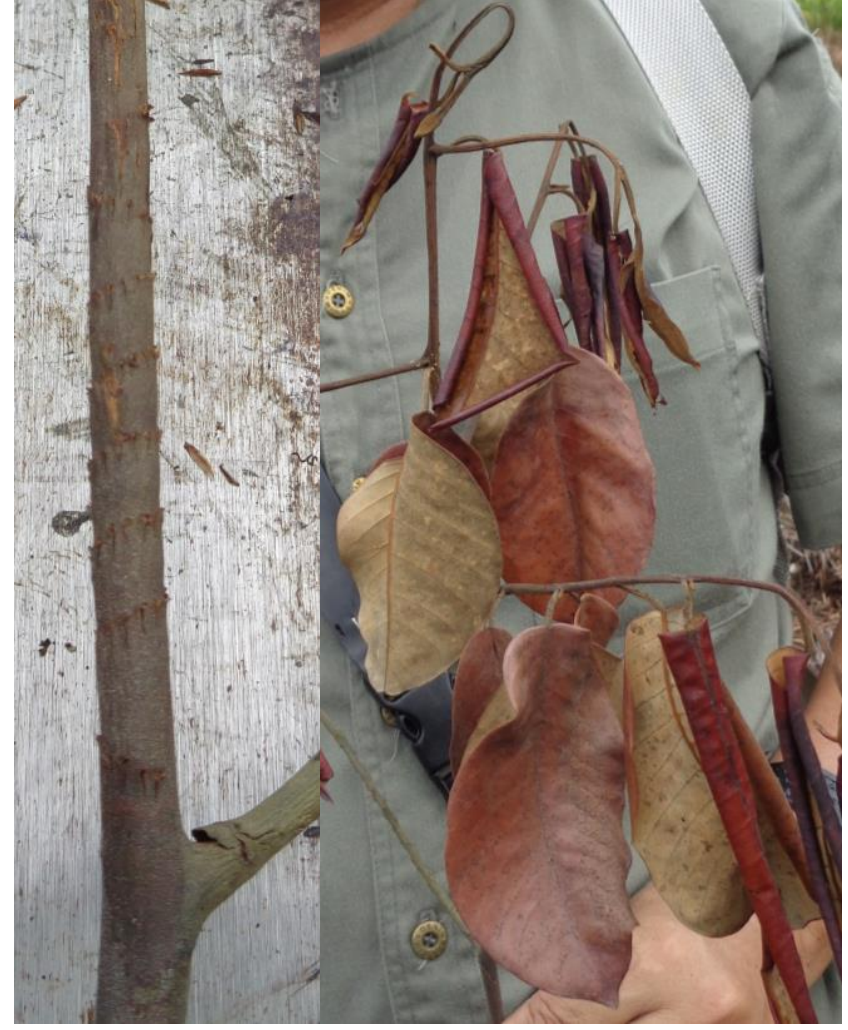

Figure 3. Main shoot and twigs attacked by borer (left), and leaving upper shoot dried, browned, and dead (right)

\section{ACKNOWLEDGEMENTS}

This project was funded by DIPA Pusat Litbang Hutan 2018. Authors wish to thank for partial contribution provided by Project collaboration between Komatsu Forest Research and Development Agency. We are also grateful to management and field staff of KPHP Tasik Besar Serkap for their field assistance and also to Research and Development Section of PT. Riau Andalan Pulp and Paper for their kind help during planting time.

\section{REFERENCES}

Andriesse J P. 1988. Nature and Management of Tropical Peat Soil. FAO Peat Soils Bull 59: 1-165.

Chamlong P, Niyomtham C, Uejirakarn W. 1991. Peat Swamp Forest Plant Species of Narathiwat, Phikulthong Study and Development Center, Royal Initiative Project, Narathiwat. So Somboon Publishing, Bangkok.

Daljeet-Singh K. 1975. A preliminary survey of insect attack on seedlings and saplings in Bukit Belata forest reserve. Malaysian For 38: 14-16.

Daljeet-Singh, K. 1975. A preliminary survey of insect attack on seedlings and saplings in Bukit Belata forest reserve. Malaysian For. 38: 14-16.

Darwo, Bogidarmanti R. 2016. Prospek budidaya Bintangur (Callophyllum soulatri) untuk dikembangkan di lahan gambut. The cultivation of Bintangur (Callophyllum soulatri) prospects to be developed in peatlands. Pros Sem Mas Masy Biodiv Indon 2 (2): 267270. [Indonesian] 
Hirano T, Kusin K, Limin S, Osaki M. 2015. Evapotranspiration of tropical peat swamp forests. Global Change Biol. 21: 1914-1927.

Jauhiainen, J, Kerojoki O, Silvennoinen H, Limin S, Vasander H. 2014. Heterotrophic respiration in drained tropical peat is greatly affected by temperature - a passive ecosystem cooling experiment. Environ Res Lett 9: 105013.

KPHP TBS. 2013. Kesatuan Pengelolaan Hutan Produksi Model Tasik Besar Serkap, Rencana pengelolaan hutan jangka panjang KPHP Model Tasik Besar Serkap. KPHP Model Tasik Besar Serkap, Pekanbaru. [Indonesian]

Lampela M, Jauhiainen J, Sarkkola S, Vasander H. 2017. Promising native tree species for reforestation of degraded tropical peatlands. For Ecol Manag 394: 52-63.

Lavelle P. 1987. Biological processes and productivity of soils in the humid tropics. In: Lovelock J, Dickinson RE (eds). Geophysiology of Amazonian. New York, USA. John Wiley

Lu D, Moran E, Musel P. 2002. Linking Amazonian secondary succession forest growth to soil properties. Land Degrad Dev 13: 331-343.

Shamsuddin. 1991. A note on the coppicing ability of Shorea species in peat swamp in Peninsular Malaysia. J Trop For Sci 3: 301-303.

Simbolon H, Mirmanto E. 1999. Checklist of plant species in the peat swamp forest of Central Kalimantan, Indonesia. In Proceedings of the International Symposium on Tropical Peatlands, Bogor, Indonesia, 22-23 November 1999

Siregar M, Sambas EN. 1999. Floristic composition of peat swamp forest in Memsemat-Sambas, West Kalimantan. In: Proceedings of the
International Symposium on Tropical Peatlands, Bogor, Indonesia, 22-23 November 1999.

Soerianegara I, Lemmens RHMJ. 2010. Sumber Daya Nabati Asia Tenggara: 5 (1) Pohon Penghasil Kayu Perdagangan Utama. Balai Pustaka, Jakarta. [Indonesian]

Suwarno E, Kartodihardjo H, Kolopaking LM, Soedomo S. 2014. Institutional Obstacles on the Development of Forest Management Unit: The Case of Indonesian Tasik Besar Serkap. Amer J Environ Protect 2 (2): 41-50

Takahashi K, Shybuya M, Tamai Y, Saito H, Istomo, Limin SH, Segah H, Erosa P. 2001. Rehabilitation of intensively disturbed sites in peat swamp forest area in Central Kalimantan. In: Osaki M, Wijaya H, Limin SH. (ed). Rehabilitation of Peatlands and Establishment of Sustainable Agrosystem in Central Kalimantan. LIPI - JSPS Core University Program in Environmental Conservation and Land Use Management of Wetland Ecosystems in Southeast Asia. wwwgeo.ees.hokudai.ac.jp/memberhome/ JspsLipi/coreuniv/agric/page $3 . h t m$

Tanit N. 1995. A study of guidelines for rehabilitating peat swamp forests. In: Annual Conference Report on Forestry for 1994 held at Wang Tai Hotel, Surat Thani, 21-25 November 1994.

Thawatchai S, Niyomtham C. 1985. Peat Swamp Forests in Thailand and Problem of Conservation. Siam Society, Bangkok.

Turjaman M, Santoso E, Susanto A, Gaman S, Limin SH, Tamai S, Osaki M, Tawaraya K. 2011. Ectomycorrhizal fungi promote growth of Shorea balangeran in degraded peat swamp forests. Wetlands Ecol Manag 19: 331-339. 